\title{
The Bosnian War Crimes Trial Simulation: Teaching Students about the Fuzziness of World Politics and International Law
}

\author{
Kurt W. Jefferson, Westminster College
}

$\mathrm{H}^{2}$ ow are political scientists supposed to teach about historical war crimes trials and their current relevance? Moreover, how can they explain to students the importance of the International Criminal Tribunal for the former Yugoslavia (ICTY), located at The Hague, Netherlands, and what this historic forum indicates about the current state of international law and world politics? During the fall semesters of 1995 and 1997, I used a group exercise to introduce international law and its political and legal ramifications to my students in Introduction to International Politics (POL 212) at Westminster College in Fulton, Missouri. ${ }^{1}$

Allowing students to participate in an actual simulated war crimes trial is an excellent way to promote enthusiasm for the study of international law and politics, facilitate debate and intellectual discourse on complex issues, and promote civility and professionalism in the conduct of serious political and legal business. In this article I will explain the Bosnian war crimes trial simulation, list its characteristics, and assess its effectiveness; describe students' reactions to the exercise; and evaluate the importance of simulation exercises as much-needed heuristic de-

Kurt W. Jefferson is an associate professor and chair of the political science department at Westminster College. He teaches comparative politics of Europe, international politics, and American politics. In 1998-99, he was recognized for excellent teaching by Westminster's student government association. Dr. Jefferson has published in the American Review of Politics, The Journal of Legislative Studies, and the Global Economic Review. He can be reached at jefferk@jaynet.wcmo.edu. vices in international politics classes. Except where indicated, all specific examples come from the 1995 class.

\section{Changing the Nature of the Classroom}

In the fall of 1995, the O.J. Simpson trial preoccupied Americans like no other story before. Few Americans could be found who did not have an opinion, informed or not, on the guilt or innocence of the former National Football League all-star. As a result, Simpson's lead defense attorneys, Robert Shapiro and Johnnie Cochran, became household names overnight. Coincidentally, I chose that semester to add to my syllabus for my introductory course in international relations a Bosnian war crimes trial simulation. Hoping to feed off their presupposed interest in the Simpson trial, I decided to give students the chance to become "Marsha Clark" or "Johnnie Cochran" in discussing issues related to international law, global politics, and the United $\mathrm{Na}$ tion's ICTY.

From the beginning, students felt that a group project where defense and prosecution teams could weigh the evidence and create cases based on international law for and against the conviction of Bosnian Serb leaders would be challenging. They also recognized the academic rigor of the assignment. They readily accepted that the simulation required learning about a region of the world that is complex and misunderstood (the former Yugoslavia), learning how to argue in logical and coherent ways through legal precedents (studying international law and arguments used by attorneys and politicians in international and domestic contexts), and bridging the gap between the political and the legal in a messy, yet definable context (Bosnia). The assignment would make their study of international relations come alive. $^{2}$

\section{The Bosnian War Crimes Trial Simulation}

The assignment was fairly simple and straightforward: "During the next two weeks we will be engaged in the 'war crimes tribunal' simulation. This simulation will focus on alleged Bosnian Serb war crimes in the protracted civil war in BosniaHerzegovina (1992-95)." The prosecution consisted of three members and they were to divide the labor accordingly. ${ }^{3}$ First, one student, in consultation with his or her fellow prosecutors, was to devise a brief statement of purpose consisting primarily of a short description of the group's duties and objectives in prosecuting Bosnian Serbs for war crimes. This statement of purpose would be given orally as part of the prosecution's opening statement, and also submitted to the professor, who was acting as the court's judge. Another prosecutor was required to develop a short written statement listing the names of indicted individuals and the crimes, with a brief description of evidence, for which each defendant would be tried. Finally, the third prosecutor was to write a brief opening statement outlining the prosecution's case and arguments and deliver the brief orally on the first day of the trial.

The three students who served as 
defense attorneys had responsibilities nearly identical to the prosecution's. One student developed a brief statement of purpose, which included a short report defending the Bosnian Serbs' actions as other than war crimes. A second student developed a report setting forth the defense's philosophy and offering detailed arguments countering the prosecution's case. The third defense attorney had the job of preparing an opening statement outlining the defense's case to be read in court. In the 1995 class, a seventh student served as associate judge. He was responsible for creating a list of precedents in war crimes decrees and trials dealing with human rights violations. These legal (and political) documents served as the general legal guide for both sides in the trial. Legal precedents used by the judges to weigh evidence included the Nuremberg Trial (194546), the Geneva Conventions on the Law of War (1949), the Genocide Convention (1949), the Krasnodar Trial (1943), the Geneva Convention on the Treatment of Prisoners in War (1899), the Bergen-Belson Trial (1945), the Zyklon B Trial (1946), and the Adolph Eichmann Trial (1961).

The trial was similar to a "mock trial" (Vile and Van Dervort 1994) but was less formal. The studentattorneys made their cases based on historical precedents. The prosecution argued that the Nuremberg and Tokyo war crimes precedents were appropriate, i.e., that the political leaders and military commanders of the Bosnian Serbs had committed crimes against humanity and should be convicted of such. The defense argued that not only did command responsibility based on the Yamashita precedent ${ }^{4}$ become a problem in some of these cases, but that the nature of the war crimes themselves were not verifiable because the war was occurring as the war crimes tribunal was hearing the case. ${ }^{5}$ The associate judge and I had decided after the opening statements which defendants would be put on trial and what was admissible in terms of evidence. The prosecution sought to convict 15 Bosnian Serbs but, due to time limitations, we narrowed the scope of the trial to deal with the four major figures: Radovan Karadzic, political leader of the Bosnian Serbs; Ratko Mladic, the military general of the Bosnian Serb forces; Zeljko Meakic, the head of the Omarska prison camp in Omarska, Bosnia-Herzegovina; and Milan Martic, the leader of the Croatian Serbs. The class had discussed and recognized, prior to beginning the simulation, that Croats, Muslims, and Serbs had all committed atrocities since the commencement of armed conflict in 1992 and that individuals from each ethnic group had been indicted at The Hague for war crimes. The defense brought this to the court's attention during the trial but, again in the interest of making the case manageable, the Serbs were chosen for prosecution because students had access to the most information on these individuals' cases.

In 1993, the UN Security Council created a war crimes tribunal on the Balkans. Eleven judges were impaneled to hear evidence and issue indictments and convictions according to international legal precedents. The chief judge was an Italian professor of international law, Antonio Cassesse. The first chief prosecutor was Richard J. Goldstone, a judge on the South African supreme court. He began his work in July 1994. The ICTY had a budget in its first two years of $\$ 22$ million (Rourke 1995, 295).

To prepare for the simulation, the students spent many long, out-ofclass, late-night sessions in the library and residence hall wings during which the members of each legal team briefed each other and discussed angles for argumentation in court. The prosecution and defense were each given an entire class period to make their cases. Each made opening statements prior to their class period to submit evidence. While submitting evidence, the prosecution in the 1997 simulation, introduced a taped conversation with a Croatian student who resided on the Westminster campus. The witness described the atrocities committed in Bosnia by all parties, including Muslims and Croats, but especially by Serbs. Students found the main evidence and facts related to firsthand testimony of witnesses they used to make their case on the International Coalition for Justice's "War Criminal Watch" homepage (www.wcw.org). ICJ is affiliated with the American Bar Association. They also found information on the ICTY's homepage (www.un.org/icty). The "War Criminal Watch" homepage has the actual ICTY indictments of war criminals in the former Yugoslavia, as well as other information on UN war crimes trials.

\section{Student Response and Lessons Learned}

The professor-judge (me), with the help of the associate judge, arrived at the final verdict after fully hearing both the prosecution and defense. The associate judge spent the unit researching international legal precedents via the Internet (mainly the Lexis/Nexis legal reference system) and various reference books such as The International Relations Dictionary (Plano and Olton 1988), The Encyclopedia of the Holocaust (Gutman 1990), Encyclopedic Dictionary of International Law (Parry et al. 1986) and Amnesty International Report 1995. After deliberating privately with the associate judge, I issued my decree. I began by commending the prosecution for "linking the defendants to the rules of law that apply in the context of the Bosnian civil war, extensively documenting the atrocities of that war and which laws were violated, [and explaining] why the need for an international forum is appropriate even if political overtones may emanate from this tribunal." I further noted that the defense had done a very good job of "questioning the role of international law in cases where war and blurred geopolitics have occurred, defending low-level commanders and soldiers in times of war, [and] making the case for those caught in the horrors of an ambiguous war." My verdict for the four men on trial read:

1. The court finds Radovan Karadzic guilty of crimes against humanity and genocide based on the precedents set by 
past international war crimes tribunals.

2. The court finds Ratko Mladic guilty of crimes against humanity and genocide. Both of these men willingly and purposely foisted a system of genocide and the intent to exterminate on the Muslim peoples of Bosnia. For this they are sentenced to life in prison in absentia. ${ }^{6}$

3. The court exonerates Milan Martic. The defense's argument that this individual took orders and was not party to any unusual circumstances in the conduct of war is tenable given the fact that his actions were not directed at one person specifically, but at a general war target: Zagreb, the capital of Croatia. To convict him would be to convict all commanders from each ethnic army.

4. The court finds Zeljko Meakic guilty of crimes against humanity for willfully and purposely carrying out wanton and destructive acts against Muslims in the Omarska camp. He is in violation of numerous past international laws. He is sentenced to 15-25 years in prison in absentia. Although the court may seem contradictory in its decision, a different standard of law applies to political leaders and military leaders than rank and file officers and commanders.

Students were satisfied with the verdict. The defense was, however, slightly disappointed that any verdict was rendered at all. I had refused to throw the case out when petitioned to do so based upon lack of jurisdiction. ${ }^{7}$ I realized, of course, that the simulation would be finished and lose its essence if the defense's request was granted. So, as one must in all simulations, I fudged and adjusted the parameters of the classroom exercise.

Students welcomed the opportunity to break away from the standard classroom lecture mode. They appreciated the independence that legal and political research brought them. Students took their roles in defending or prosecuting Bosnian Serbs very seriously. Most importantly, students learned about the history, culture, and politics of a complex region of Europe while learning more about international law and politics generally.

\section{Conclusion: Evaluation of the Simulation}

Students were graded individually. Separate reports based on their role on one of the legal teams constituted the major written component of their grade. Their rhetorical skills, legal and logical insights, and courtroom demeanor determined the oral component. The associate judge was graded on the quality of his research and ability to view and evaluate the proceedings in a neutral manner. Based on students' performance, I feel confident that the war crimes trial simulation brought contemporary politics and history alive to a new generation of students, that the simulation helped students begin to appreciate that in international law the lines between what is political and legal are usually blurred, and that it led students to engage important issues of political and legal adjudication.

The simulation introduced the Nuremberg Trials to the 1990 s student who may not have been familiar with the military tribunal that formally ended the Second World War. A number of books and resources related to war crimes trials were recommended to students, and one was used as a course textbook in $1997 .{ }^{8}$ A good classroom exercise can bring history and today's events into focus palpably for students. This "interpersonal simulation" created "a scenario in which students ... were genuine players in the system" (Baker 1994, 253). Stu- dents learned the fuzziness of international law in a practical and applied way. War crimes tribunals are about politics and law simultaneously. War crimes trial simulations allow students more interested in politics to focus on those aspects related to leadership and political authority while, at the same time, allowing pre-law students to hone their legal argumentation, logic, and evidence-building skills. Too many Americans think in black and white terms when law and politics mesh. Hence, a war crimes trial gives students an opportunity to see that the truth is often murky, blurry, and, well, fuzzy.

Political scientists must constantly seek to make the classroom an active environment for learning and pedagogy. A simulated war crimes trial builds students' confidence in their understanding of various foreign contexts and ability to assess legal and political arguments. The simulation was, perhaps, more valuable in this regard than larger Model UN or Model European Union programs because individual students cannot hide in groups or teams. They are held accountable for the knowledge they have accumulated and are forced to speak and make presentations to the "court" and the rest of their classmates.

I believe the simulation could have been improved by focusing more on the war crimes of all groups involved in the civil war in Bosnia, including Muslims and Croats. In my Spring 1999 class, I asked students to prosecute and defend a mixture of the three ethnic groups in order to make more objective judgments about the collective guilt or innocence of the various peoples involved in the political struggle in Bosnia between 1992 and 1995. I also believe that a fuller discussion of the philosophical pros and cons of war crimes trials is appropriate given the vehement oppo- 
sition to them by many. The recent indictment of Chile's General Pinochet by the Spanish government and subsequent extradition trial in Britain has renewed the debate over the legitimacy of courts of international law and even international law itself.

The Bosnian war crimes trial simulation taught students much. Most importantly, it taught them that in the realm of politics and law, contextual fuzziness is not always a hindrance to making legal arguments one way or another.

\section{Notes}

1. The simulation was one of four units making up the course.

2. Numerous scholarly articles and books were used to introduce students to BosniaHerzegovina (e.g., Cohen 1995; Glenny 1996; Remington 1993; Roskin 1992).

3. POL 212 had seven students in 1995 , six in 1997 , and 15 in 1999.

4. Tomoyuki Yamashita was a Japanese general who was convicted and executed for issuing orders to subordinates who committed crimes in war. The Yamashita precedent is synonymous with command responsibility in times of war and the culpability that resides with the high command for war crimes if they are committed. The historian Richard Lael covers the post-war fate of the Japanese general and the Pacific war crimes trials in his excellent 1982 book on the case.
5. Ironically, in the middle of the semester (November 1995), the Dayton peace accords were signed and hostilities ceased in Bosnia. On the very day the accords were announced, a visiting political scientist, Vojislav Stanovcic of the University of Belgrade, spoke at Westminster College on the future of nations and nation-states to a large audience of students and interested locals from the community.

6. In real life, the ICTY was not allowed to try defendants in absentia (Rourke 1995, 296).

7. Both in 1995 and 1997, heated opening sessions led to serious examination of jurisdictional issues. Moreover, the political and moral consequences of war crimes trials were a source of argument among students. The simulation proved itself an excellent goad to critical assessment of the pros and cons of war crimes trials and their institutional and political biases.

8. In 1997, one of the course's texts was Joseph Persico's Nuremberg: Infamy on Trial (1995). This is an excellent book that reads like an historical novel. He describes the personalities that shaped the proceedings and how the legal arguments were made at Nuremberg in 1945-46. In 1999, I adopted Michael P. Scharf's Balkan Justice: The Story Behind the First International War Crimes Trial Since Nuremberg (1997). This book is a thorough review of the legal precedents related to war crimes trials and a specific case study of the inchoate stages of the ICTY from a former U.S. State Department legal specialist who witnessed firsthand its evolution.

\section{References}

Amnesty International. 1995. Amnesty Interna tional Report 1995. London: Amnesty International Publications.

Baker, Nancy V. 1994. "Oyez, Oyez, Oyez: The Trials of Teaching the Supreme Court." PS: Political Science and Politics 27(June): 253-55.

Cohen, Lenard J. 1995. Broken Bonds: Yugoslavia's Disintegration and Balkan Politics in Transition. 2nd ed. Boulder: Westview Press.

Glenny, Misha. 1996. The Fall of Yugoslavia: The Third Balkan War. 3rd rev. ed. New York: Penguin.

Gutman, Israel. 1990. Encyclopedia of the Holocaust. Vol. 4. New York: Macmillan.
Lael, Richard L. 1982. The Yamashita Precedent: War Crimes and Command Responsibility. Wilmington, DE: Scholarly Resources.

Parry, Clive, et al., eds. 1986. Encyclopedic Dictionary of Intemational Law. New York: Oceana Publications.

Persico, Joseph E. 1995. Nuremberg: Infamy on Trial. New York: Penguin.

Plano, Jack C., and Roy Olton. 1988. The International Relations Dictionary. 4th ed. Santa Barbara, CA: ABC-Clio.

Remington, Robin Alison. 1993. "Bosnia: The Tangled Web." Current History 92(November): $364-69$

Roskin, Michael G. 1992. “The Bosnian
Serb Problem: What We Should and Should Not Do." Parameters: U.S. Army War College Quarterly 22(Winter): 21-32.

Rourke, John T. 1995. International Politics on the World Stage. 5th ed. Guilford, CT: Dushkin Publishing Group/Brown \& Benchmark Publishers.

Scharf, Michael P. 1997. Balkan Justice: The Story Behind the First International War Crimes Trial Since Nuremberg. Durham: Carolina Academic Press.

Vile, John R., and Thomas R. Van Dervort. 1994. "Revitalizing Undergraduate Programs through Intercollegiate Mock Trial Competition." PS: Political Science and Politics 27(December): 714-17. 